\title{
Gambaran keton urin pada pasien dewasa dengan tuberkulosis paru di RSUP Prof. Dr. R. D. Kandou Manado
}

\author{
${ }^{1}$ H. Silvio B. Wibowo \\ ${ }^{2}$ Glady I. Rambert \\ ${ }^{2}$ Mayer F. Wowor
}

\author{
${ }^{1}$ Kandidat Skripsi Fakultas Kedokteran Universitas Sam Ratulangi Manado \\ ${ }^{2}$ Bagian Patologi Klinik Faklutas Kedokteran Universitas Sam Ratulangi Manado \\ Email: vio.x1.slab10@gmail.com
}

\begin{abstract}
Tuberculosis is chronic infection caused by Mycobacterium Tuberculosa. Patient with tuberculosis it could lead to reduction of appetite and vomit cause by side effects of tuberculosis medication. This condition can lead to formation of ketone bodies as a consequence of inadequate glucose level. Its excessive level in the body will be also excreted in the urine (ketonuria) and its existence in urine is abnormal. This study was aimed to find the keton urine in adult patient with pulmonary tuberculosis at Prof. R. D. Kandou Hospital Manado. This was a descriptive observational study with consecutive sampling method from October-November 2016. Samples were mid-stream urine of 30 adult patients with pulmonary tuberculosis that met the inclusion criteria. The results showed that 25 patients (84\%) had normal urine (negative ketonuria), 3 patients (10\%) with trace result, 1 patients with low ketonuria, and a patient with moderate ketonuria. Conclusion: Most of the patients had normal urine (negative ketonuria).
\end{abstract}

Keywords: pulmonary tuberculosis, urinalysis, keton.

\begin{abstract}
Abstrak: Tuberkulosis merupakan infeksi kronis yang disebabkan oleh bakteri Mycobacterim Tuberculosa. Pasien dengan tuberkulosis dapat mengalami penurunan nafsu makan juga muntah oleh karena efek samping obat. Hal ini dapat mencetuskan terbentuknya badan keton dalam tubuh oleh karena pasokan glukosa yang kurang. Keton dapat digunakan sebagai energi pengganti yang didapat dari metabolisme lemak. Jumlahnya yang berlebih juga akan keluar didalam urin (ketonuria) dan keberadaanya dalam urin bukanlah keadaan yang normal. Tujuan penelitian ini untuk mengetahui gambaran keton urin pada pasien tuberkulosis paru dewasa di RSUP Prof. R. D. Kandou. Jenis penelitian ialah deskriptif observasional dan pengambilan sampel dengan consecutive sampling dari bulan OktoberNovember 2016. Sampel penelitian ialah urin sewaktu pada 30 pasien dewasa dengan tuberkulosis paru yang telah memenuhi kriteria inklusi. Hasil pemeriksaan menunjukkan bahwa dari 30 pasien dewasa dengan tuberkulosis paru didapatkan sebanyak 25 pasien (84\%) dengan hasil normal atau negative, 3 pasien (10\%) dengan hasil trace, 1 pasien (3\%) dengan low dan moderate. Simpulan: Gambaran keton urin pada penelitian ini sebagian besar didapat hasil normal.
\end{abstract}

Kata kunci: tuberkulosis paru, urinalisis, keton.

Tuberkulosis (TB) adalah penyakit infeksi kronik yang disebabkan oleh Mycobacterium Tuberculosa yang dapat menyerang berbagai organ tubuh seperti paru-paru, ginjal, tulang dan otak. Penyakit tuberkulosis ditularkan dari orang ke orang melalui udara lewat bersin, batuk, atau meludah. World Health Organization (WHO) pada tahun 1993 menyatakan bahwa tuberkulosis sebagai global health 
emergency. ${ }^{1}$ Pada tahun 2015 diperkirakan 10,4 juta kasus tuberkulosis baru diseluruh dunia. penduduk dunia terinfeksi tuberkulosis dan 1,5 juta diantaranya meninggal dunia. Lebih dari $95 \%$ kematian pada tuberkulosis terjadi pada negara berpenghasilan rendah dan menengah. Secara global di tahun yang sama terdapat sekitar 480.000 pasien yang berkembang menjadi multidrug-resistant tuberkulosis (MDR-TB). ${ }^{2}$

Laporan WHO dalam Global Case Report tahun 2016 dengan jumlah penduduk Indonesia mencapai 254 juta orang, prevalensi tuberkulosis di Indonesia mencapai 1,6 juta kasus dengan pertumbuhan 1 juta kasus per tahun yang menjadikan Indonesia penyumbang tuberkulosis terbesar di dunia setelah India (2,5 juta). ${ }^{2}$ Badan Pusat Statistik Provinsi Sulawesi Utara dalam laporannya "Sulawesi Utara Dalam Angka" melaporkan jumlah kasus kematian menurut 10 jenis penyakit utama di RSUP Manado di tahun 2014 dimana kematian menurut tuberculosis menempati posisi ke4 dengan jumlah kasus sebanyak 10 kasus dan jumlah penderita tuberkulosis paru di manado pada tahun 2014 sebanyak 1.328 penderita. ${ }^{3}$ Urinalisis merupakan pemeriksaan urin yang terdiri dari pemeriksaan makroskopik, mikroskopik atau sedimen, dan kimia urin yang dilakukan secara tepat, dapat diandalkan, aman, dan efektif. Pada pemeriksaan kimia digunakan pemeriksaan carik celup yang terdiri dari pemeriksaan $\mathrm{pH}$, berat jenis, protein, glukosa, keton, eritrosit, bilirubin, urobilinogen, nitrit, dan leukosit. Untuk pemeriksaan mikroskopik dilakukan melalui evaluasi sedimen dan hasil sentrifugasi urin. Salah satu komponen dari pemeriksaan urinalisis adalah pemeriksaan kimia keton. ${ }^{4}$

Keton merupakan produk dari pemecahan asam lemak. Keberadaan keton dalam urin menandakan bahwa tubuh menggunakan lemak sebagai energi. ${ }^{5}$ Pada saat tubuh mengalami kelaparan dimana jumlah karbohidrat tidak mencukupi sebagai energi, asam lemak akan diubah menjadi badan keton yang kemudian beredar dalam darah, proses pembentukan keton disebut sebagai ketogenesis. Suatu keadaan dimana jumlah keton yang diproduksi melebihi jumlah normal disebut sebagai ketosis, yang kemudian dapat ditemukan dalam darah yang dikenal sebagai ketonemia atau dalam urin sebagai ketonuria. $^{6}$

Pada pasien dengan tuberkulosis ditemukan gangguan nutrisi mulai dari ringan hingga berat. Infeksi tuberkulosis menyebabkan penurunan nafsu makan pada seseorang yang mengakibatkan hati memproduksi keton yang digunakan sebagai sumber energi. ${ }^{7}$ Berdasarkan penguraian latar belakang diatas penulis tertarik untuk mengetahui gambaran keton pada pasien tuberkulosis di RSUP. Prof. DR. R. D. Kandou.

\section{METODE PENELITIAN}

Penelitian ini merupakan studi deskriptif dengan desain potong lintang. Penelitian ini dilaksanakan di poliklinik paru dan instalasi rawat inap bagian penyakit dalam RSUP. Prof. Dr. R. D. Kandou Manado selama bulan Oktober sampai November 2016. Sampel penelitian ini adalah sampel urin sewaktu dari semua pasien tuberkulosis paru dewasa dalam kurun waktu dan kriteria yang telah ditentukan dengan cara non-probability sampling jenis consecutive sampling.

\section{HASIL PENELITIAN DAN BAHASAN}

Sesuai dengan hasil penelitian di RSUP. Prof. Dr. R. D. Kandou Manado yang dilaksanakan pada bulan Oktober 2016-November 2016 terdapat 30 pasien tuberkulosis paru yang memenuhi kriteria inklusi.

Pada Tabel 1 tentang distribusi usia secara keseluruhan mencakup pasien rawat inap dan rawat jalan dimana terdapat 4 pasien $(13,3 \%)$ masing-masing pada rentang usia 18-25 tahun dan 26-35 tahun, 8 pasien $(26,7 \%)$ pada usia 36-45 tahun, 6 pasien $(20 \%)$ masing-masing pada usia 4655 tahun dan 56-65 tahun, dan 2 pasien $(6,7 \%)$ pada usia 66-75 tahun. Penelitian 
yang dilakukan oleh Laily dkk di puskemas tuminting manado juga sesuai dengan hasil, dimana pasien yang paling banyak menderita tuberkulosis adalah kelompok pasien yang berusia $26-45$ tahun $(39,8 \%){ }^{8}$ Namun laporan WHO tahun 2016 menyatakan bahwa penderita tuberkulosis di Indonesia paling banyak di usia 25-34 tahun. $^{2}$

Tabel 1. Distribusi Usia

\begin{tabular}{ccc}
\hline \multirow{2}{*}{ Usia } & \multicolumn{2}{c}{ Total } \\
\cline { 2 - 3 } & Jumlah & $\%$ \\
\hline $18-25$ & 4 & $13.3 \%$ \\
$26-35$ & 4 & $13.3 \%$ \\
$36-45$ & 8 & $26.7 \%$ \\
$46-55$ & 6 & $20.0 \%$ \\
$56-65$ & 6 & $20.0 \%$ \\
$66-75$ & 2 & $6.7 \%$ \\
Total & 30 & $100.0 \%$ \\
\hline
\end{tabular}

Mobilitas dan interaksi sosial yang lebih tinggi pada orang dengan usia produktif, yang harus bekerja untuk memperoleh pemasukan guna memenuhi kebutuhan keluarga, memungkinkan mereka untuk terinfeksi dari orang lain menjadi lebih tinggi. Meningkatnya kebiasaan merokok pada usia muda di negara-negara miskin juga menjadi salah satu faktor dari banyaknya kejadian tuberkulosis paru pada usia produktif. ${ }^{1,9}$

Pada Tabel 2 dari keseluruhan sampel pasien rawat inap dan rawat jalan didapatkan sebanyak 20 pasien $(66,7 \%)$ merupakan pasien laki-laki dan sebanyak 10 pasien $(33,3 \%)$ adalah pasien perempuan.

Tabel 2. Distribusi Jenis Kelamin

\begin{tabular}{ccc}
\hline \multirow{2}{*}{ Jenis Kelamin } & \multicolumn{2}{c}{ Total } \\
\cline { 2 - 3 } & Jumlah & $\%$ \\
\hline Laki-laki & 20 & $66.70 \%$ \\
Perempuan & 10 & $33.30 \%$ \\
Total & 30 & $100 \%$ \\
\hline
\end{tabular}

Laporan WHO menunjukkan hasil yang sama bahwa insiden dan prevalensi tuberkulosis lebih banyak ditemukan pada jenis kelamin laki-laki daripada perempuan namun penelitian yang dilakukan oleh Azizi dkk mendapati jumlah penderita tuberkulosis paru di Bandung lebih banyak pada perempuan ketimbang pada lakilaki. ${ }^{2,10}$

Adanya perbedaan biologi pada lakilaki dan wanita, seperti perbedaan tingkat imunitas menjelaskan tentang perbedaan perbandingan penyakit infeksi TB paru. Laki-laki juga dilaporkan lebih sering mengkonsumsi alkohol dan rokok. Perbedaan aktivitas sehari-hari menyebabkan kemungkinan pajanan infeksi tuberkulosis lebih banyak terhadap lakilaki. Laki-laki memiliki tingkat pengetahuan tentang tuberkulosis lebih tinggi dari perempuan, sehingga menyebabkan adanya perbedaan gender dalam mencari bantuan kesehatan kepada tenaga profesional juga dapat mempengaruhi tingginya pencatatan kejadian tuberkulosis paru pada laki-laki. ${ }^{9}$

Tabel 3 menunjukkan hasil jenis kasus tuberkulosis dari keseluruhan sampel pasien rawat inap dan rawat jalan, yaitu sebanyak 13 pasien (43\%) merupakan pasien baru, 8 pasien (27\%) masing-masing merupakan pasien putus obat dan pasien relaps serta 1 pasien (3\%) gagal terapi. Data serupa juga didapat pada penelitian oleh Sihotang dkk di puskesmas Bahu Malalayang dimana sebanyak 53 pasien $(91,8 \%)$ merupakan pasien baru. ${ }^{11}$ Pada penelitian Laily dkk di puskesmas Tuminting tahun 2015, sebanyak 196 pasien $(100 \%)$ adalah pasien baru. ${ }^{8}$

Tabel 3. Distribusi Jenis Kasus TB

\begin{tabular}{ccc}
\hline \multirow{2}{*}{ Jenis Kasus TB } & \multicolumn{2}{c}{ Total } \\
\cline { 2 - 3 } & Jumlah & $\%$ \\
\hline Baru & 13 & $43 \%$ \\
Putus Obat & 8 & $27 \%$ \\
Relaps & 8 & $27 \%$ \\
Gagal Terapi & 1 & $3 \%$ \\
Total & 30 & $100 \%$ \\
\hline
\end{tabular}

Penyebab terjadinya kasus putus berobat (defaulted) adalah karena tingkat pengetahuan pasien yang rendah sehingga motivasi untuk berobat penuh kurang dan 
lebih suka berobat ke pengobatan alternatif, adanya efek samping dari obat tuberkulosis, kurangnya pengetahuan pasien mengenai lama durasi waktu pengobatan, dan kurangnya dukungan dari keluarga sekitar. Kebanyakan pasien defaulted menghentikan pengobatan segera setelah merasa agak baikan atau sekitar dua bulan setelah pengobatan dimulai. Kesalahan persepsi yang ada di masyarakat bahwa merasa baik/sehat adalah berarti sembuh meningkatkan angka putus obat. ${ }^{9}$

Pada Tabel 4, dari pasien yang telah diperiksa, terdapat 4 pasien juga menderita hipertensi, 5 pasien menderita diabetes, 5 Pasien menderita menderita asam urat, dan 6 pasien menderita penyakit ginjal. Hasil penelitian oleh Susilayanti dkk menunjukkan dari 149 penderita tuberkulosis paru BTA positif didapatkan diabetes melitus sebagai penyakit penyerta terbanyak $(77,2 \%) .{ }^{12}$ Pada pasien dengan gangguan ginjal terjadi penurunan sistem imun. Infeksi kronik akan lebih menurunkan kapasitas pertahanan lokal melalui mekanisme pertahanan yang tidak spesifik sehingga pasien dengan gangguan ginjal memiliki risiko 10-15 kali lebih besar untuk mendapatkan infeksi TB. ${ }^{13}$

Tabel 4. Distribusi Penyakit Penyerta

\begin{tabular}{cc}
\hline Penyakit Penyerta & Jumlah \\
\hline Hipertensi & 4 \\
Diabetes Melitus & 5 \\
Asam Urat & 5 \\
Penyakit Ginjal & 6 \\
\hline
\end{tabular}

Hasil pada Tabel 5 memaparkan jenis pengobatan pada pasien yakni sebanyak 24 pasien $(80 \%)$ menggunakan pengobatan OAT kategori 1 dan 6 pasien (20\%) menggunakan pengobatan OAT kategori 2 . Pengobatan kategori 1 terdiri atas Rifampicin, Isoniazid, Pirazinamid, dan Etambutol dan sedangkan pada pengobatan kategori 2 hampir sama dengan kategori 1 hanya diberi tambahan streptomisin. Obatobat tersebut memiliki efek samping seperti nyeri perut, mual, dan muntah meskipun jarang terjadi dan kejadiannya dapat bervariasi. $^{14}$ Jika pasien mengalami muntah, maka tubuh dapat memproduksi keton sebagai konsekuensi akibat hilangnya karbohidrat. Tubuh akan memetabolisme lemak menjadi keton sebagai energi pengganti. $^{5,15}$

Tabel 5. Distribusi Jenis OAT

\begin{tabular}{ccc}
\hline \multirow{2}{*}{ Jenis OAT } & \multicolumn{2}{c}{ Total } \\
\cline { 2 - 3 } & Jumlah & $\%$ \\
\hline Kategori 1 & 24 & $80 \%$ \\
Kategori 2 & 6 & $20 \%$ \\
Total & 30 & $100 \%$ \\
\hline
\end{tabular}

Pada Tabel 6 didapatkan data urinalisis pada pasien diabetes mellitus dan nondiabetes mellitus, dari 5 pasien tuberkulosis dengan diabetes mellitus terdapat 1 pasien (3\%) yang terdapat ketonuria (low) dan dari 25 pasien tuberkulosis yang tidak menderita diabetes mellitus terdapat 3 pasien (9\%) dengan ketonuria (trace) dan 1 pasien $(3 \%)$ dengan ketonuria (high).

Tabel 6. Distribusi hasil kimia keton pada pasien DM dan Non-DM

\begin{tabular}{lccc}
\hline \multirow{2}{*}{ Hasil } & $\begin{array}{c}\text { Pasien } \\
\text { DM }\end{array}$ & $\begin{array}{c}\text { Pasien } \\
\text { Non- } \\
\text { DM }\end{array}$ & Total \\
\cline { 2 - 4 } & $\%$ & $\%$ & Jumlah(\%) \\
\hline Negative & $13 \%$ & $70 \%$ & $25(83 \%)$ \\
Trace & $0 \%$ & $10 \%$ & $3(10 \%)$ \\
Low & $3 \%$ & $0 \%$ & $1(3 \%)$ \\
Moderate & $0 \%$ & $3 \%$ & $1(3 \%)$ \\
High & $0 \%$ & $0 \%$ & $0(0 \%)$ \\
Total & $17 \%$ & $83 \%$ & $30(100 \%)$ \\
\hline
\end{tabular}

Tabel 7 menunjukkan hasil pemeriksaan kimia keton pada pasien dengan dan tanpa penyakit penyerta. Penyakit penyerta yang pada penelitian ini dibagi menjadi hipertensi, diabetes melitus, penyakit ginjal, dan asam urat. Hasil pemeriksaan menunjukkan pada pasien dengan penyakit penyerta sebanyak 1 pasien $(3 \%)$ masing-masing terdapat low dan moderate ketonuria. Pada pasien tanpa penyakit penyerta didapatkan 3 pasien dengan trace ketonuria. 
Tabel 7. Distribusi hasil kimia keton pada pasien dengan dan tanpa penyakit penyerta

\begin{tabular}{cccc}
\hline Hasil & $\begin{array}{c}\text { Dengan } \\
\text { Penyerta }\end{array}$ & $\begin{array}{c}\text { Tanpa } \\
\text { Penyerta }\end{array}$ & Total \\
\cline { 2 - 4 } & $\%$ & $\%$ & $\begin{array}{c}\text { Jumlah } \\
(\%)\end{array}$ \\
\hline Netral & $40 \%$ & $43 \%$ & $25(83 \%)$ \\
Trace & $0 \%$ & $10 \%$ & $3(10 \%)$ \\
Low & $3 \%$ & $0 \%$ & $1(3 \%)$ \\
Moderate & $3 \%$ & $0 \%$ & $1(3 \%)$ \\
High & $0 \%$ & $0 \%$ & $0(0 \%)$ \\
Total & $47 \%$ & $53 \%$ & $30(100 \%)$ \\
\hline
\end{tabular}

Tuberkulosis merupakan penyakit kronik paru yang disebabkan oleh infeksi dari Mycobacterium Tuberculosa. ${ }^{1,18}$ Tidak jarang penderita tuberkulosis juga disertai penyakit penyerta yang lain seperti diabetes mellitus. WHO menyatakan pasien dengan diabetes mellitus 3 kali lebih beresiko terserang tuberculosis. ${ }^{2}$ Pada Penderita diabetes mellitus mengalami penurunan fungsi daya tahan tubuh, sehingga penderita tuberkulosis lebih rentan terinfeksi tuberkulosis. Pada pasien diabetes mellitus yang tidak terkontrol, akan terjadi keadaan dimana tubuh tidak mampu mengolah glukosa dalam darah menjadi energi, sehingga energi yang dibutuhkan oleh tubuh akan dibentuk melalui metabolisme lemak dan dibentuklah keton. Asetoasetat, Bhydroxybutyrate, dan aseton merupakan badan keton. Dalam keadaadan defisiensi karbohidrat, tubuh akan membentuk badanbadan keton di hati. $\beta$-hidroksibutirat dan asetoasetat merupakan badan keton yang utama dan kaya akan energi. Aseton terbentuk dari dekarboksilasi asetoasetat secara spontan dan aseton adalah penyebab timbulnya aroma manis dalam nafas seseorang dengan ketoasidoasis.

Keberadaan keton dalam urine tidaklah normal. ${ }^{5,15}$ Keton hanya akan dibentuk saat terjadi defisiensi karbohidrat dan tidak dibentuknya energi dari glukosa. Keton kemudian akan beredar dalam darah dan diedarkan ke seluruh tubuh melalui pembuluh darah menuju organ-organ penting seperti otak dan otot dimana keton dibutuhkan sebagai energi pengganti ${ }^{5,16}$
Tidak setiap pasien diabetes mellitus dapat ditemukan ketonuria. Hal ini disebabkan oleh karena kerja insulin. Dimana insulin bekerja menghambat terjadinya lipolysis dan memicu terjadinya lipogenesis. Insulin menghambat ketogenesis dengan memicu defosforilasi dari hormone-sensitif lipase dan mengaktifasi lipogenesis dengan menstimulasi asetil CoA karboksilase. Di dalam adiposit, defosforilasi dari hormonesensitif lipase menghambat pemecahan trigliserida menjadi asam lemak dan gliserol. Hal ini menyebabkan penurunan substrat yang tersedia untuk ketogenesis. $^{17,18}$

Karena keton bersifat asam, tubuh akan menghasilkan basa sebagai buffer untuk mempertahankan keseimbangan asam-basa tubuh. Bila tubuh terus-menerus menggunakan keton sebagai energi, suatu saat cadangan basa tubuh akan habis dan hal ini akan menimbulkan keadaan darurat yaitu ketoasidosis yang dapat mengancam nyawa. Inilah dimana pentingnya pemeriksaan keton pada pasien diabetes mellitus.

Keadaan seperti ketoasidosis diabetik, kelaparan, hamil, ketoasidosis alkoholik, diet tinggi protein rendah karbohidrat, muntah, diare, dan hipoglikemi merupakan keadaan-keadaan yang dapat memicu produksi keton dalam tubuh. ${ }^{5,9}$ Badan keton tidak hanya diukur sebagai bagian dari urinalisis lengkap, tetapi dilakukan untuk mengklasifikasi atau mengobati beberapa populasi pasien seperti pasien yang masuk rumah sakit dengan keadaan darurat (terutama pasien pediatri), diabetes onset juvenile, atau pasien dengan toksemia pada kehamilan. Setelah terapi insulin dan cairan pada diabetes dengan hiperglikemi dan ketosis, jaringan $\beta$-hidroksibutirat diubah kembali menjadi asetoasetat yang menyebabkan peningkatan sementara dari eksresi asetoasetat di urin meskipun keadaan klinisnya membaik. ${ }^{19}$

Penjelasan tentang hubungan tuberkulosis paru dewasa dan pemeriksaan keton urin masih kurang lazim dilaporkan atau diteliti. Keterbatasan penelitian ini ialah kurangnya 
informasi mengenai kelengkapan status pasien, jumlah sampel, anamnesis pasien, waktu, dan kepustakaan yang masih terbatas mengenai ketonuria pada tuberkulosis

\section{SIMPULAN}

Berdasarkan hasil penelitian pada 30 pasien tuberkulosis paru dapat disimpulkan bahwa sebagian besar memperlihatkan hasil keton normal. Walaupun demikian, hasil ketonuria trace,low dan moderate ditemukan pada beberapa pasien.

\section{SARAN}

Berdasarkan hasil penelitian, bahasan, dan simpulan yang didapat dari data yang dikumpulkan, maka penulis menyarankan agar jumlah sampel dan waktu penelitian ditingkatkan untuk menghindari terjadinya bias dalam penelitian. Juga perlu dilakukan penelitian lebih lanjut dengan dilengkapi bukti hasil laboratorium mengenai keton pada pasien tuberkulosis paru agar hasil yang ditemukan lebih akurat dan dapat dipercaya.

\section{DAFTAR PUSTAKA}

1. Amin Z, Bahar A. Tuberkulosis Paru. Dalam: Setiati S, Alwi I, Sudoyo A W, Simadibrata M, Setiyohadi B, Syam A F, editor. Buku Ajar Ilmu Penyakit Dalam. Edisi 6. Jakarta: InternaPublishing; 2014. h. 864.

2. Global Tuberculosis Report 2016. World Health Organization. ISBN 978924 1565394.

3. Sulawesi Utara Dalam Angka 2015. Badan Pusat Statistik Provinsi Sulawesi Utara. ISSN 0215-2274.

4. Aulia D, Lydia A. Urinalisis. Dalam: Setiati S, Alwi I, Sudoyo A W, Simadibrata M, Setiyohadi B, Syam A F, editor. Buku Ajar Ilmu Penyakit Dalam. Jilid 1. Edisi 6. Jakarta: InternaPublishing; 2014. h. 231.

5. Devkota BP. Ketones. October $30^{\text {th }} 2015$. [cited 2016 Dec 14]. Available from: http://emedicine.medscape.com/articl e/2087982-overview\#showall

6. Gupta KB, Gupta R, Atreja A, Verma M, Vishvkarma S, et al. Tuberculosis and Nutrition. Lung India 2009;26:9-
11.

7. Emery PW. Metabolic Changes in Malnutrition. Eye 2005;19:1029-34.

8. Laily DW, Rombot DV, Lampus BS. Karakteristik Pasien Tuberkulosis Paru di Puskesmas Tuminting. Jurnal Kedokteran Komunitas dan Tropik 2015;3(1):1-5.

9. Panjaitan F. Karakteristik Penderita Tuberkulosis Paru Dewasa Rawat Inap di Rumah Sakit Umum DR. Soedarso Pontianak Periode September-November 2010. Skripsi. Pontianak: Sarjana Universitas Tanjungpura; 2012.h.1-16.

10.Azizi FH, Husin UA, Rusmartini T. Gambaran Karakteristik Tuberkulosis Paru dan Ekstra Paru di BBKPM Bandung Tahun 2014. Prosiding Pendidikan Dokter 2014:862.

11.Sihotang RH, Lampus B, Pandelaki AJ. Gambaran Penderita Tuberkulosis Paru yang Berobat Menggunakan DOTS di Puskesmas Bahu Malalayang I Periode JanuariDesember 2012. Jurnal Kedokteran Komunitas dan Tropik 2013;1(1):6872.

12.Susilayanti EY. Medison I. Erkadius. Profil Penderita Penyakit Tuberkulosis Paru BTA Positif yang Ditemukan di BP4 Lubuk Alung periode Januari 2012 - Desember 2012. Jurnal Kesehatan Andalas 2014;3(2):151-155.

13.Mimi N, Medregoniu, Olteanu M, Golli A, Olteanu M, Maceseanu A, Medregoniu. Tuberculosis and Chronic Renal Failure; Therapy Patterns. Current Health Sciences Journal 2011;37(2):106-8.

14.Arbex MA, Varella MCL, Siqueira HR, Mello FAF. Antituberculosis drugs: Drug Interaction, adverse effects, and use in special situations. $\mathbf{J}$ Bras Pneumol 2010;36(5):626-640.

15.Simerville JA, Maxted WC, Pahira JJ. Urynalisis: A Comprehensive Review. Am Fam Physician 2005;71(6):1154-6.

16.Lieseke CL. Urinalysis. Lieseke CL. Chemical Examination of Urine and Feces. In: Lieseke CL, Zeibig EA, editors. Essential of medical laboratory practice. Philadelphia, PA: 
F.A Davis; 2012. pp. 392-400, 414417.

17. Comstock JP, Garber AJ. Ketonuria. In: Walker H K, W D Hall, Hurst JW. Clinical Methods: The History, Physical, and Laboratory Examinations. 1990;3.

18. Roxe DM. Urinalysis. In: Walker H K, W D
Hall, Hurst JW. Clinical Methods: The History, Physical, and Laboratory Examinations. 1990;3.

19.European Confederation of Laboratory Medicine. European Urinalysis Guidelines. Scand J Lab Invest 2000;60:1-96. 